\title{
Role of toll-like receptor 4 in acute neutrophilic lung inflammation induced by intratracheal bacterial products in mice
}

\author{
Wakako Yamada' \\ Sadatomo Tasaka' \\ Hidefumi Koh' \\ Mie Shimizu' \\ Yuko Ogawa' \\ Naoki Hasegawa' \\ Taku Miyasho \\ Kazuhiro Yamaguchi' \\ Akitoshi Ishizaka' \\ 'Division of Pulmonary Medicine, \\ Keio University School of Medicine, \\ Shinjuku-ku, Tokyo, Japan; '2Laboratory \\ of Veterinary Biochemistry, School \\ of Veterinary Medicine, Rakuno \\ Gakuen University, Ebetsu, Japan
}

Correspondence: Sadatomo Tasaka Division of Pulmonary Medicine, Keio University School of Medicine 35 Shinanomachi, Shinjuku-ku Tokyo 160-8582, Japan

Tel +8 I 353633793

Fax $+8 I 333532502$

Email tasaka@cpnet.med.keio.ac.jp
Background: Toll-like receptors (TLRs) represent a conserved family of innate immune recognition receptors. Among TLRs, TLR4 is important for the recognition of Gram-negative bacteria, whereas TLR2 recognizes cell wall constituents of Gram-positive microorganisms, such as peptidoglycan (PGN).

Methods: To evaluate the role of TLR4 in the pathogenesis of acute lung injury induced by Escherichia coli endotoxin (lipopolysaccharide; LPS) or PGN, we compared inflammatory cell accumulation in bronchoalveolar lavage (BAL) fluid and lung pathology between $\mathrm{C} 3 \mathrm{H} / \mathrm{HeJ}$ (TLR4 mutant) and wild-type $\mathrm{C} 3 \mathrm{H} / \mathrm{HeN}$ mice. The levels of proinflammatory cytokines and chemokines in plasma and BAL fluid and nuclear factor- $\kappa \mathrm{B}(\mathrm{NF}-\kappa \mathrm{B})$ translocation in the lung were also evaluated.

Results: In $\mathrm{C} 3 \mathrm{H} / \mathrm{HeJ}$ mice, LPS-induced neutrophil emigration was significantly decreased compared with $\mathrm{C} 3 \mathrm{H} / \mathrm{HeN}$ mice, whereas $\mathrm{PGN}$-induced neutrophil emigration did not differ. Differential cell count in BAL fluid revealed comparable neutrophil recruitment in the alveolar space. In TLR4 mutant mice, LPS-induced upregulation of tumor necrosis factor-alpha (TNF- $\alpha$ ), $\mathrm{KC}$, and CXCL10 in plasma and BAL fluid was attenuate, which was not different after PGN. $\mathrm{NF}-\kappa \mathrm{B}$ translocation in the lung was significantly decreased in $\mathrm{C} 3 \mathrm{H} / \mathrm{HeJ}$ compared with $\mathrm{C} 3 \mathrm{H} / \mathrm{HeN}$ mice, whereas PGN-induced NF- $\mathrm{\kappa B}$ translocation was not different.

Conclusion: These results suggest that TLR4 mediates inflammatory cascade induced by Gram-negative bacteria that is locally administered.

Keywords: rodent, TLR4, endotoxin, neutrophils, NF- $\kappa B$

\section{Introduction}

Lung infection is one of the leading causes of illness and death worldwide. Bacteria or their constituents in the lungs induce the expression of multiple genes of inflammatory mediators and adhesion molecules, leading to neutrophil margination within the microvasculature, adhesion to endothelial cells, and transmigration between endothelial cells into the alveolar space (Hogg and Doerschuk 1995; Doerschuk et al 1999). The transcription of these genes, including chemokines, adhesion molecules, and early response cytokines, is regulated at least in part by the nuclear factor- $\kappa \mathrm{B}$

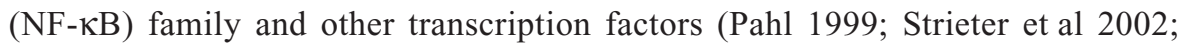
Ciesielski et al 2002).

Toll-like receptors (TLRs) represent a conserved family of innate immune recognition receptors that play key roles in detecting microbes, initiating innate immune responses, and linking innate and adaptive immunity (Akira et al 2006). Over the last few years, it has become evident that both the recognition and the subsequent response to pathogens are mainly transferred by TLRs (Takeuchi et al 1999; Yamamoto et al 2004; Ding et al 2005; Akira et al 2006). Ten TLRs have been described so far, among 
which TLR2 and TLR4 are the family members that have been investigated to the greatest extent (Takeuchi et al 1999; Yamamoto et al 2004).

TLR4, the endotoxin (lipopolysaccharide; LPS) receptor, is important for the recognition of Gram-negative bacteria, whereas TLR2 has been designated the major receptor for Gram-positive bacteria by virtue of its capacity to recognize major cell wall constituents of Gram-positive microorganisms, such as peptidoglycan (PGN), lipoteichoic acid, and lipoproteins (Takeuchi et al 1999; Schwartz 2001; Branger et al 2004).

The role of TLRs in the inflammatory process has been the subject of several recent investigations. However, most of the studies evaluated cellular response in vitro or systemic reaction such as survival rate, and a few studies have focused on the role of TLRs in lung inflammatory change following locally administered stimuli (Fan et al 2003; Faure et al 2004; Schurr et al 2005). In the present series of experiments, we sought to determine the role of TLR4 in acute inflammatory response induced by bacterial components of gram-positive and gram-negative bacteria. We first evaluated LPS- or PGNinduced neutrophil emigration within the lungs, comparing $\mathrm{C} 3 \mathrm{H} / \mathrm{HeJ}$ (Tlr4Lps-d) mice that carry a defective allele of TLR4 gene and wild-type $\mathrm{C} 3 \mathrm{H} / \mathrm{HeN}$. Differential cell counts and levels of proinflammatory cytokines (TNF- $\alpha$, IFN- $\gamma$ ) and chemokines (KC, CXCL10) were examined in bronchoalveolar lavage (BAL) fluid. We also evaluated the activation of NF- $\kappa \mathrm{B}$ after intratracheal challenge of LPS or PGN using lung homogenate.

\section{Materials and methods}

\section{Animals and reagents}

Female $\mathrm{C} 3 \mathrm{H} / \mathrm{HeN}$ and $\mathrm{C} 3 \mathrm{H} / \mathrm{HeJ}$ mice were purchased from CLEA Japan (Tokyo, Japan). All mice were housed in the Keio University Animal Resource Center, and all experiments received institutional approval, conforming to $\mathrm{NIH}$ guidelines. The animals were provided water and rodent chow ad libitum for at least 3 days prior to the experiment. Escherichia coli endotoxin (serotype B:55) was purchased from Sigma Chemicals (St. Louis, MO). PGN from Staphylococcus aureus was purchased from Fluka (Buchs, Switzerland).

\section{Experimental protocol for acute lung injury in mice}

Eight-week old mice weighing approximately $22 \mathrm{~g}$ were anesthetized using ketamine hydrochloride ( $80-100 \mathrm{mg} / \mathrm{kg}$ i.m.) and acepromazine maleate (5-10 mg/kg i.m.). Either E. coli
LPS $(3.0 \mathrm{mg} / \mathrm{kg}$ given as a solution of $1.2 \mathrm{mg} \mathrm{LPS} / \mathrm{ml}$ phosphate buffer solution [PBS]) or PGN (1.0 mg/kg given as a solution of $0.4 \mathrm{mg}$ PGN/ml PBS) was instilled intratracheally, and control mice received PBS $(2.5 \mathrm{ml} / \mathrm{kg})$. After $6 \mathrm{~h}$, the lungs were removed and fixed using intratracheal instillation of $6 \%$ glutaraldehyde at $22 \mathrm{~cm}-\mathrm{H} 2 \mathrm{O}$ or lavaged with three separate $1.0 \mathrm{ml}$ volumes of PBS containing $0.6 \mathrm{mM}$ EDTA, each volume being instilled and withdrawn three times. Blood samples were obtained from the inferior vena cava and subjected to differential count of circulating leukocytes.

\section{Inflammatory cell accumulation in the lung}

Pulmonary neutrophils were quantified by morphometric analysis in histological sections as previously described (Tasaka et al 2003). Paraffin-embedded histologic 5- $\mu \mathrm{m}$ sections of lungs were cut and stained with hematoxylin and eosin. Neutrophil emigration was quantitated by counting the number of neutrophils in 200 randomly selected alveoli and was expressed as the number of neutrophils per 100 alveoli. Samples were also taken from the control mice that received PBS instillation. After the cell counting, the BAL fluid was centrifuged, and the supernatants were stored at $-80{ }^{\circ} \mathrm{C}$ until cytokine measurement. The levels of murine TNF- $\alpha$, IFN- $\gamma$, and $\mathrm{KC}$ in the plasma and $\mathrm{BAL}$ fluid were quantitated using a suspension array system (Bio-Plex; Bio-Rad, Hercules, CA). The murine CXCL10 was measured using an ELISA kit (R\&D Systems, Minneapolis, MN) according to the manufacturer's instruction. The minimum detectable dose of CXCL10 was $2.2 \mathrm{pg} / \mathrm{mL}$.

\section{Nuclear protein extraction from the lungs}

Mice were anesthetized as above and received intratracheal instillation of PBS, LPS (3.0 mg/kg), or PGN (1.0 mg/kg). After $3 \mathrm{~h}$, the lungs were removed and frozen immediately in liquid nitrogen. Nuclear extracts were prepared as previously described (Mizgerd et al 2002; Tasaka et al 2003). Briefly, the isolated lungs were homogenized in $3 \mathrm{ml}$ of ice-cold Buffer A (10 mM HEPES, $1.5 \mathrm{mM} \mathrm{MgCl2}, 10 \mathrm{mM}$ $\mathrm{KCl}, 0.5 \mathrm{mM}$ DTT, $0.5 \mathrm{mM}$ PMSF), with a $0.1 \%$ volume of Nonidet P-40 and protease inhibitor cocktail $(1 \mathrm{mg} / \mathrm{ml}$ leupeptin, $1 \mathrm{mg} / \mathrm{ml}$ aprotinin, $10 \mathrm{mg} / \mathrm{ml}$ soy bean trypsin inhibitor, $1 \mathrm{mg} / \mathrm{ml}$ pepstatin). Following 10-min incubation on ice, the homogenates were centrifuged at $850 \times \mathrm{g}$ for $10 \mathrm{~min}$ at $4^{\circ} \mathrm{C}$. The pellets were resuspended in $3 \mathrm{ml}$ of Buffer $\mathrm{A}$ and centrifuged at $1,400 \times \mathrm{g}$ for $10 \mathrm{~min}$ at $4{ }^{\circ} \mathrm{C}$. 
The crude nuclear pellets were resuspended in $50 \mu 1$ of Buffer B (20 mM HEPES, 1.5 mM MgCl2, 0.42 M NaCl, 0.2 mM EDTA, 25\% vol/vol glycerol, $0.5 \mathrm{mM}$ DTT, $0.5 \mathrm{mM}$ PMSF) with protease inhibitor cocktail (as described above) and incubated for $30 \mathrm{~min}$ on ice. Nuclear extracts were recovered following centrifugation at $20,000 \times \mathrm{g}$ for $15 \mathrm{~min}$ at $4{ }^{\circ} \mathrm{C}$ and stored at $-80{ }^{\circ} \mathrm{C}$. The protein concentration of the nuclear extracts was determined by bicinchoninic acid assay. The regression curve was obtained using bovine serum albumin as the standard.

\section{Electrophoretic mobility shift assay and supershift assay}

Electrophoretic mobility shift assay (EMSA) was performed following the manufacturer's protocol (Gel Shift Assay Systems; Promega, Madison, WI) with several modifications (Tasaka et al 2003). The double strand NF- $\kappa \mathrm{B}$ consensus oligonucleotide probe (5'-AGTTGAGGGGACTTTCCCAGGC-3') was end-labeled with [32P]-ATP $(3,000 \mathrm{Ci} / \mathrm{mmol}$ at $10 \mathrm{mCi} / \mathrm{ml})$ using $\mathrm{T} 4$ polynucleotide kinase. Binding reactions $(10 \mu \mathrm{l})$ containing $35 \mathrm{fmol} / \mathrm{ml}$ of oligonucleotide probe, $5 \mathrm{mg}$ of nuclear extract and $5 \times$ binding buffer $(10 \mathrm{mM}$ Tris- $\mathrm{HCl}, 1 \mathrm{mM} \mathrm{MgCl}$, $50 \mathrm{mM} \mathrm{NaCl}, 0.5 \mathrm{mM}$ EDTA, $0.5 \mathrm{mM}$ DTT, 4\% vol/vol glycerol, $0.5 \mathrm{mg}$ poly dI-dC) were incubated for $20 \mathrm{~min}$ at room temperature. Following the binding procedure, 10 -fold loading buffer (250 mM Tris-HCl, 0.2\% bromophenol blue, $40 \%$ glycerol, $0.2 \%$ xylane cyanol) was added to stop the reaction. The reactions were subjected to nondenaturing $6 \%$ polyacrylamide gel electrophoresis (NOVEX, San Diego, CA) in $0.5 \times$ TBE buffer (45 mM Tris-boric acid, $1 \mathrm{mM}$ EDTA-2H2O) at $65 \mathrm{~V}$ for $85 \mathrm{~min}$. Gels were vacuum dried for $45 \mathrm{~min}$ and exposed to X-ray film (BMR; Kodak, Rochester, NY) at $-70^{\circ} \mathrm{C}$. The relative intensity of each band was quantitated using scanning laser densitometry and Scion Image Software (Scion Corporation, Frederick, MD).

Supershift assays were performed as previously described (Malley et al 2003). Nuclear proteins $(0.3 \mathrm{mg} / \mathrm{ml})$ were incubated with $3.5 \mathrm{nM}\left[{ }^{32} \mathrm{P}\right] \mathrm{ATP}-$ labeled NF- $\kappa \mathrm{B}$ consensus oligonucleotide and an antibody against one subunit of $\mathrm{NF}-\kappa \mathrm{B}(0.2 \mathrm{mg} / \mathrm{ml})$ for $30 \mathrm{~min}$ prior to electrophoresis. Polyclonal antibodies against RelA (sc-7151) and p50 (sc-1192) were purchased from Santa Cruz Biotechnology (Santa Cruz, CA). Protein-oligonucleotide complexes were separated from protein-free oligonucleotides by polyacrylamide gel electrophoresis and detected by autoradiography. Independent experiments with proteins collected from the lungs of different mice yielded consistent results.

\section{Statistics}

Data are presented as the mean \pm SEM. One-way analysis of variance and Scheffe's test were used. Differences were considered statistically significant when $\mathrm{p}<0.05$.

\section{Results}

\section{Neutrophil emigration in alveolar spaces}

To evaluate the effect of TLR 4 gene mutation on neutrophil emigration induced by bacterial products, emigrated neutrophils were quantified morphologically in histologic sections. The number of neutrophils per 100 cross-sectioned alveolar spaces is shown in Figure 1a. In $\mathrm{C} 3 \mathrm{H} / \mathrm{HeN}$, or wild type mice, intratracheal LPS induced marked neutrophil emigration within the lungs, whereas a much smaller extent of neutrophil emigration occurred after LPS in $\mathrm{C} 3 \mathrm{H} / \mathrm{HeJ}$ or TLR4-mutant mice. The number of emigrated neutrophils was significantly less in $\mathrm{C} 3 \mathrm{H} / \mathrm{HeJ}$ than in $\mathrm{C} 3 \mathrm{H} / \mathrm{HeN}$ mice $(\mathrm{p}<0.05)$. PGN induced significant neutrophil emigration within the lungs, and there was no difference in the emigrated neutrophils between the two strains examined. The doses of LPS and PGN that we selected caused similar degrees of neutrophil emigration. Representative microscopic findings are shown in Figure 1b.

Neutrophil emigration in alveolar spaces following intratracheal instillation of bacterial product was also evaluated using differential cell count in BAL fluid (Figure 2). In $\mathrm{C} 3 \mathrm{H} / \mathrm{HeN}$ mice, LPS induced remarkable increases in the counts of both total cells and neutrophils, compared with the PBS control group of the same strain $(\mathrm{p}<0.001)$. The recruitment of inflammatory cells after LPS was significantly decreased in $\mathrm{C} 3 \mathrm{H} / \mathrm{HeJ}$ mice, compared with $\mathrm{C} 3 \mathrm{H} / \mathrm{HeN}$ mice $(p<0.05)$. PGN challenge also induced significant increases in the counts of both total cells and neutrophils, which did not differ between the two strains examined. These findings suggested that TLR4 is responsible for LPS-induced, but not PGN-induced, recruitment of inflammatory cell within the lungs.

\section{Circulating WBC and neutrophil counts}

Circulating WBC and neutrophil counts in blood samples obtained from the inferior vena cava are shown in Table 1. Neither WBC nor neutrophil counts was significantly changed by intratracheal LPS administration. Although there was no significant difference between $\mathrm{C} 3 \mathrm{H} / \mathrm{HeJ}$ and $\mathrm{C} 3 \mathrm{H} / \mathrm{HeN}$ mice, leukocyte and neutrophil counts were increased by PGN instillation $(\mathrm{p}<0.05)$. The absence of TLR4 signaling made no significant difference in either circulating WBC or neutrophil counts. 


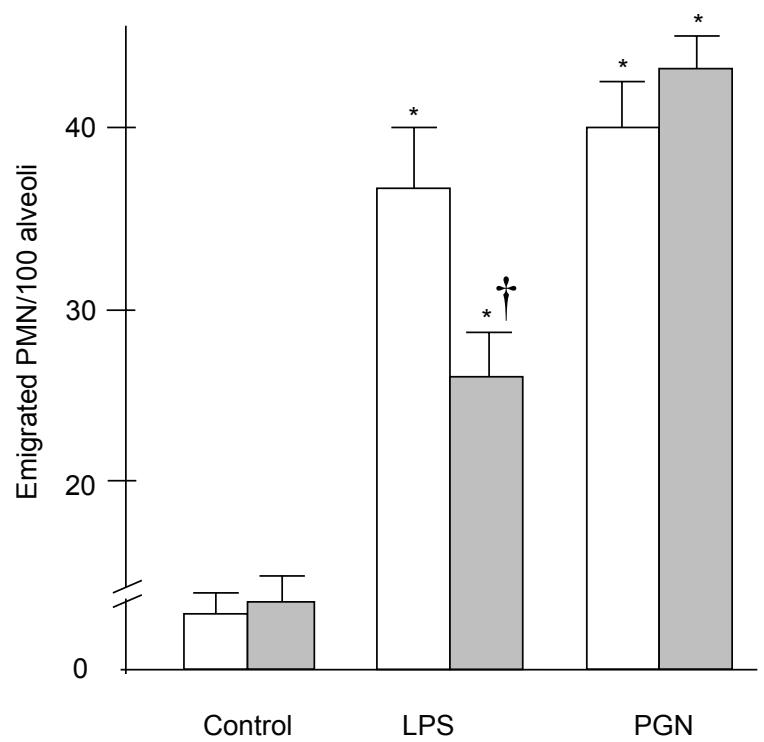

b
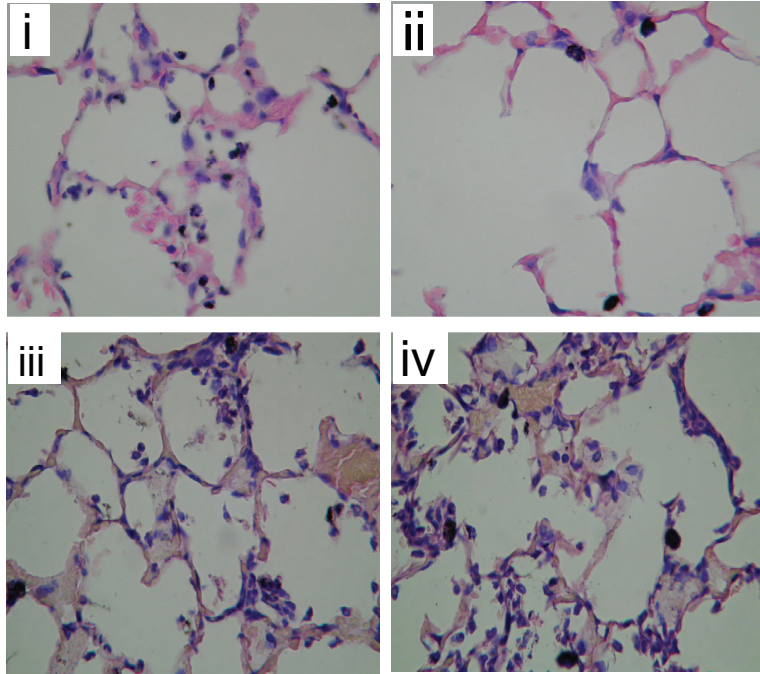

Figure I (a) Neutrophil emigration in the lung. Although LPS-induced neutrophil emigration was significantly attenuated in $\mathrm{C} 3 \mathrm{H} / \mathrm{HeJ}$ mice, $\mathrm{PGN}$-induced neutrophil accumulation did not differ between the two strains. (b) Representative example of lung pathology. Shown are images of lung sections obtained from $\mathrm{C} 3 \mathrm{H} / \mathrm{HeN}$ (i and iii) and $\mathrm{C} 3 \mathrm{H} / \mathrm{HeJ}$ (ii and iv) mice 6 hours after intratracheal instillation of LPS ( $\mathrm{i}$ and ii) or PGN (iii and iv). Significant attenuation of neutrophil emigration was observed in the C3H/HeJ mice followed by LPS instillation.

Notes: Open columns: $\mathrm{C} 3 \mathrm{H} / \mathrm{HeN}$ mice, Gray columns, $\mathrm{C} 3 \mathrm{H} / \mathrm{HeJ}$ mice; Data are presented as the mean $\pm \mathrm{SEM}(\mathrm{n}=6)$; ${ }^{*} \mathrm{p}<0.05$ versus control; ${ }^{\dagger} \mathrm{p}<0.05$ versus $\mathrm{C} 3 \mathrm{H} / \mathrm{HeN}$ mice. Magnification $\times 400$.

Abbreviations: LPS, lipopolysaccharide; PGN, peptidoglycan.

a

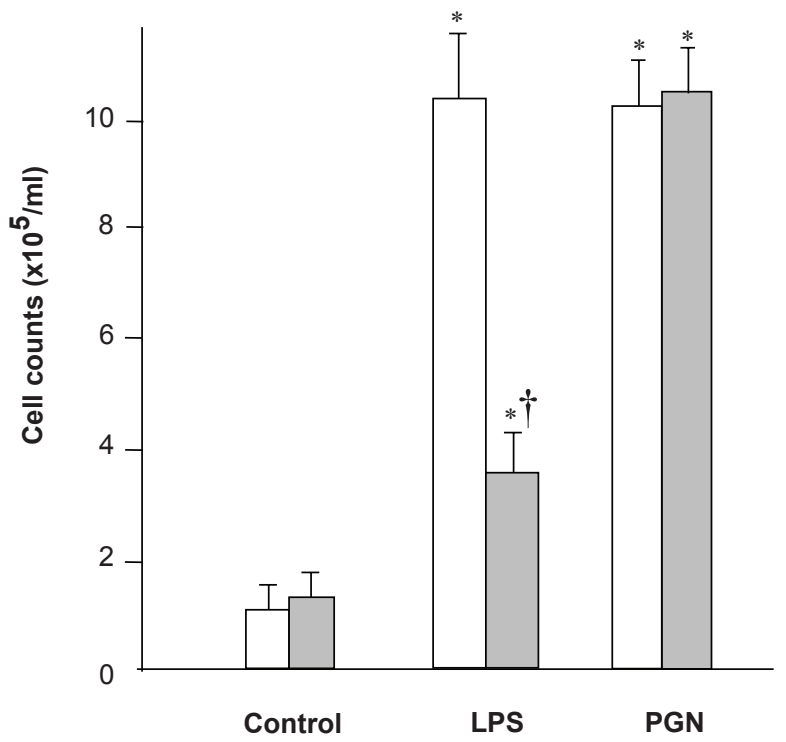

b

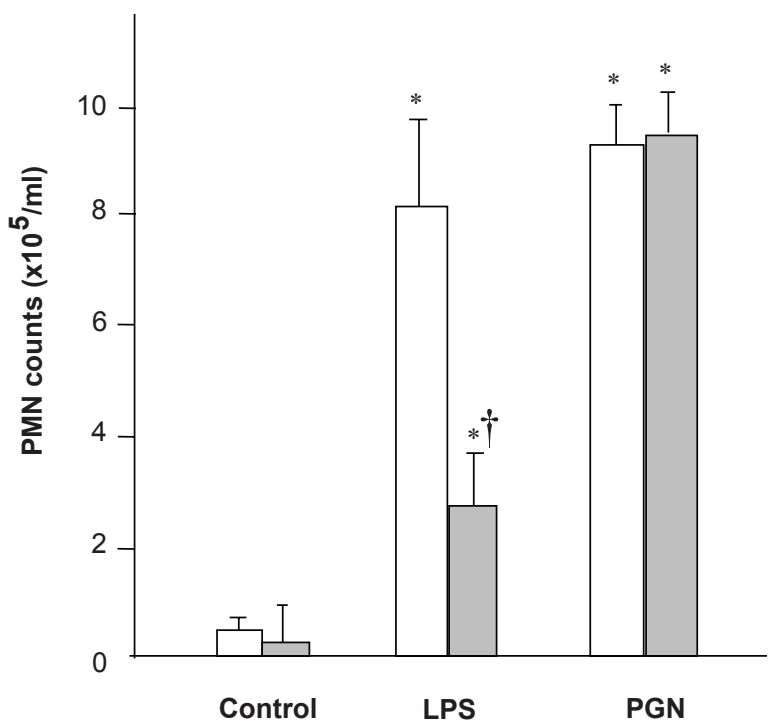

Figure 2 Cellularity of bronchoalveolar lavage (BAL) fluid. The total cell (a) and neutrophil (b) counts in BAL fluid after LPS challenge were significantly decreased in C3H/ $\mathrm{HeJ}$ mice, compared with $\mathrm{C} 3 \mathrm{H} / \mathrm{HeN}$ mice $(\mathrm{P}<0.0 \mathrm{I})$. PGN challenge also induced significant increases in the counts of both total cells and neutrophils, which did not differ between the two strains examined.

Notes: Open columns, $\mathrm{C} 3 \mathrm{H} / \mathrm{HeN}$ mice; Gray columns, $\mathrm{C} 3 \mathrm{H} / \mathrm{HeJ}$ mice; Data are presented as the mean $\pm \mathrm{SEM}(\mathrm{n}=6)$; ${ }^{*} \mathrm{p}<0.05$ versus control; ${ }^{\dagger} \mathrm{p}<0.05$ versus $\mathrm{C} 3 \mathrm{H} /$ $\mathrm{HeN}$ mice.

Abbreviations: LPS, lipopolysaccharide; PGN, peptidoglycan; SEM, standard error of mean. 
Table I Circulating leukocyte and neutrophil counts

\begin{tabular}{llll}
\hline Insult & Strain & Leukocyte $(/ \mathrm{mm} 3)$ & Neutrophil $\left(/ \mathrm{mm}^{3}\right)$ \\
\hline Control & $\mathrm{C} 3 \mathrm{H} / \mathrm{HeN} \mathrm{C3H/HeJ}$ & $0.66 \pm 0.130 .78 \pm 0.21$ & $0.23 \pm 0.030 .26 \pm 0.06$ \\
LPS & $\mathrm{C} 3 \mathrm{H} / \mathrm{HeN} \mathrm{C3H/HeJ}$ & $0.56 \pm 0.050 .50 \pm 0.05$ & $0.32 \pm 0.040 .33 \pm 0.03$ \\
PGN & $\mathrm{C} 3 \mathrm{H} / \mathrm{HeN} \mathrm{C3H} / \mathrm{HeJ}$ & $1.03 \pm 0.23^{*} 1.07 \pm 0.22^{*}$ & $0.57 \pm 0.260 .56 \pm 0.28$ \\
\hline
\end{tabular}

Note: Data are presented as the mean $\pm \operatorname{SEM}(n=6) .{ }^{*} \mathrm{p}<0.05$ was considered to be significantly different from the corresponding value of the control of the same strain.

\section{Cytokine and chemokine production}

To validate the effect of TLR4 gene mutation on LPSinduced upregulation of inflammatory mediators, the levels of inflammatory cytokines (TNF- $\alpha$ and IFN- $\gamma$ ) and chemokines (KC and CXCL10) were measured in plasma and lung lavage fluid with ELISA, and the results are shown in Figures 3-6. In C3H/HeN mice, the plasma TNF- $\alpha$ level was significantly increased after LPS instillation, whereas LPS did not increase the plasma TNF- $\alpha$ level compared with the control group in $\mathrm{C} 3 \mathrm{H} / \mathrm{HeJ}$ mice (Figure $3 \mathrm{a}$ ). The TNF- $\alpha$ level in the lavage fluid sampled after LPS instillation was decreased in $\mathrm{C} 3 \mathrm{H} / \mathrm{HeJ}$ mice, compared with $\mathrm{C} 3 \mathrm{H} / \mathrm{HeN}$ mice (Figure 3b). Intratracheal PGN caused no significant change in plasma TNF- $\alpha$ levels regardless of the strain. In contrast, PGN induced significant upregulation of TNF- $\alpha$ in the lung lavage fluid, which did not differ between the two strains.

PGN instillation significantly increased the INF- $\gamma$ levels in both plasma and BAL in $\mathrm{C} 3 \mathrm{H} / \mathrm{HeJ}$ mice $(\mathrm{p}<0.05)$ but not in $\mathrm{C} 3 \mathrm{H} / \mathrm{HeN}$ mice (Figure 4). Although the plasma IFN- $\gamma$ level was not increased by LPS challenge, the IFN- $\gamma$ level in BAL fluid was significantly increased after intratracheal PGN only in C3H/HeJ mice (Figure 4).

The plasma KC level was markedly increased after LPS challenge in $\mathrm{C} 3 \mathrm{H} / \mathrm{HeN}$ mice, which was completely suppressed in TLR4 mutant mice ( $p<0.01$; Figure 5a). Intratracheal LPS upregulated the $\mathrm{KC}$ level also in BAL fluid, which was significantly greater in $\mathrm{C} 3 \mathrm{H} / \mathrm{HeN}$ than in $\mathrm{C} 3 \mathrm{H} / \mathrm{HeJ}$ mice $(\mathrm{p}<0.05$; Figure $5 \mathrm{~b})$. PGN caused significant increase in $\mathrm{KC}$ levels in lung BAL fluid compared with the a

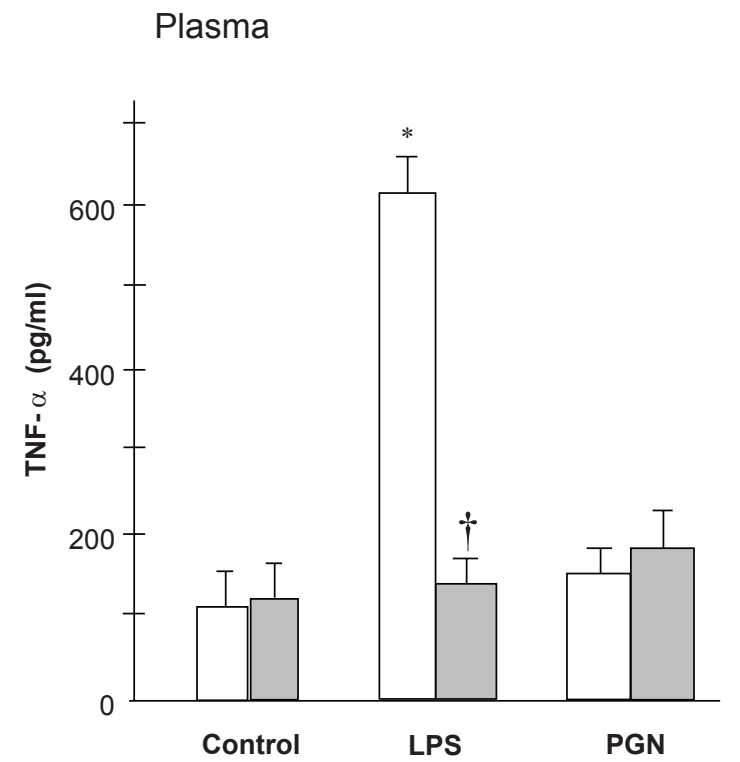

b

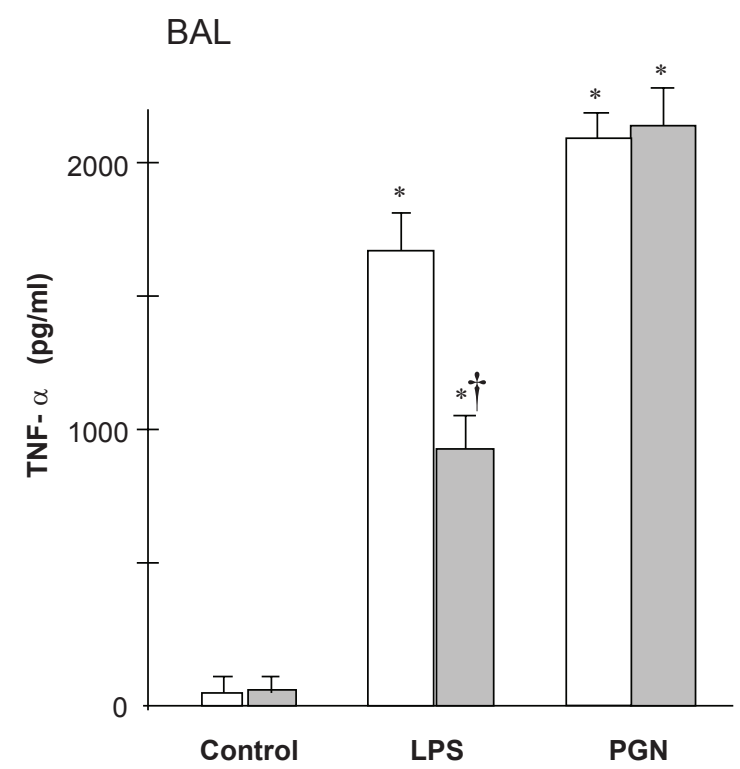

Figure 3 TNF- $\alpha$ concentration in plasma (a) and BAL fluid (b) LPS-induced increase in plasma TNF- $\alpha$ concentration was significantly attenuated in C3H/HeJ mice, compared with $\mathrm{C} 3 \mathrm{H} / \mathrm{HeN}$ mice. PGN-induced upregulation of TNF- $\alpha$ did not differ between the two strains.

Notes: Open columns, $\mathrm{C} 3 \mathrm{H} / \mathrm{HeN}$ mice; Gray columns, $\mathrm{C} 3 \mathrm{H} / \mathrm{HeJ}$ mice; Data are presented as the mean $\pm \mathrm{SEM}(\mathrm{n}=6)$; ${ }^{*} \mathrm{p}<0.05$ versus control; ${ }^{\dagger} \mathrm{p}<0.05$ versus $\mathrm{C} 3 \mathrm{H} /$ $\mathrm{HeN}$ mice.

Abbreviations: BAL, bronchoalveolar lavage; LPS, lipopolysaccharide; PGN, peptidoglycan; SEM, standard error of mean. 
a

\section{Plasma}

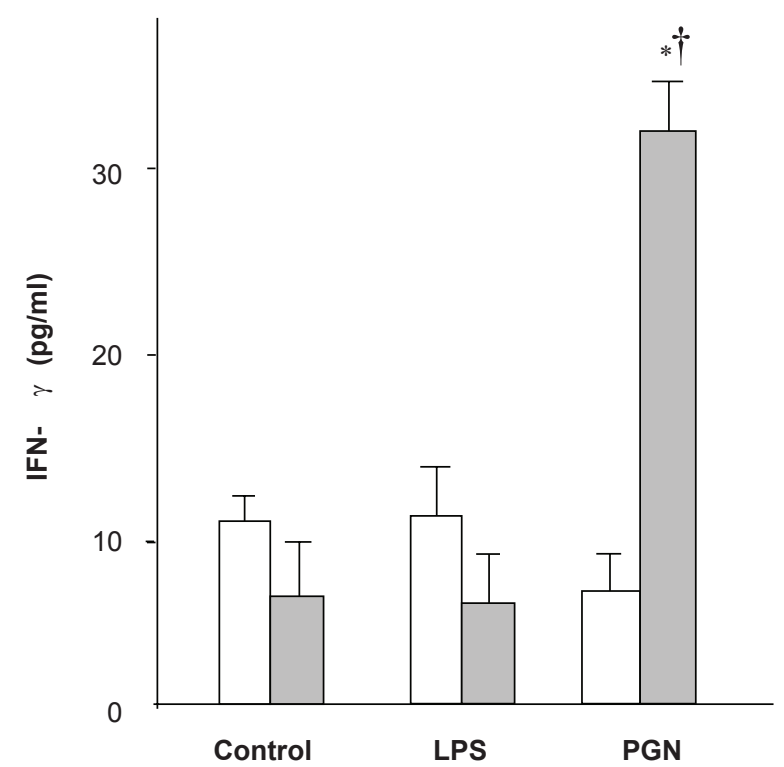

b

\section{BAL}

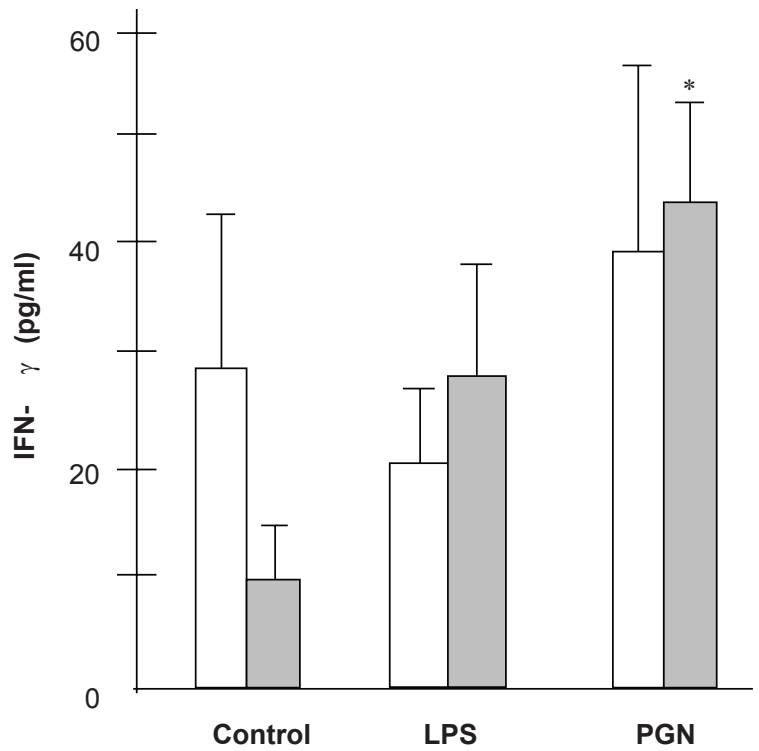

Figure 4 IFN- $\gamma$ concentration in plasma and BAL fluid. (a) PGN increased plasma IFN- $\gamma$ only in C3H/HeJ mice, whereas LPS did not change the plasma IFN- $\gamma$ level. (b) In BAL fluid, the IFN- $\gamma$ level after LPS was greater in $\mathrm{C} 3 \mathrm{H} / \mathrm{HeJ}$ than in $\mathrm{C} 3 \mathrm{H} / \mathrm{HeN}$ mice, while PGN-induced upregulation of IFN- $\gamma$ did not differ between the strains.

Notes: Open columns, $\mathrm{C} 3 \mathrm{H} / \mathrm{HeN}$ mice; Gray columns, $\mathrm{C} 3 \mathrm{H} / \mathrm{HeJ}$ mice; Data are presented as the mean $\pm \mathrm{SEM}(\mathrm{n}=6)$; ${ }^{*} \mathrm{p}<0.05$ versus control; ${ }^{\dagger} \mathrm{p}<0.05$ versus $\mathrm{C} 3 \mathrm{H} /$ $\mathrm{HeN}$ mice.

Abbreviations: BAL, bronchoalveolar lavage; IFN, interferon; LPS, lipopolysaccharide; PGN, peptidoglycan; SEM, standard error of mean.

a

Plasma

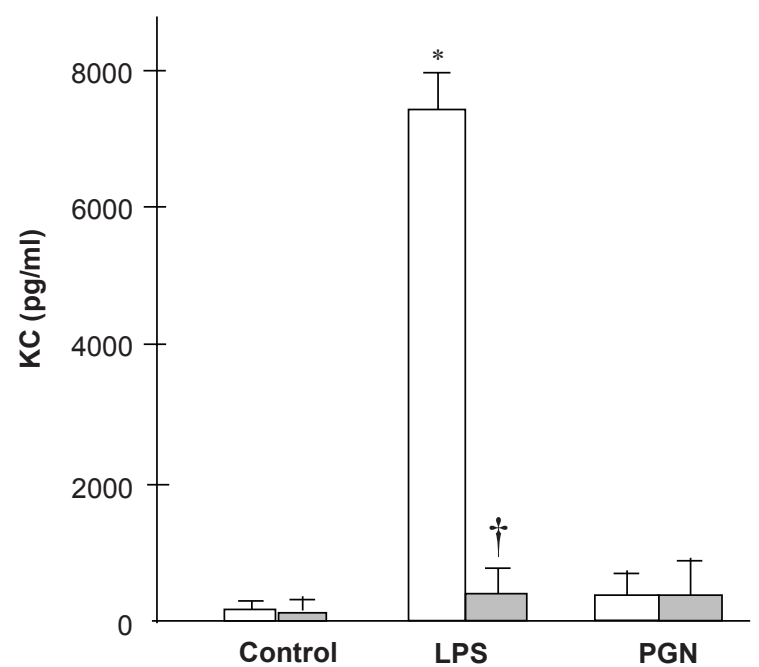

b

BAL

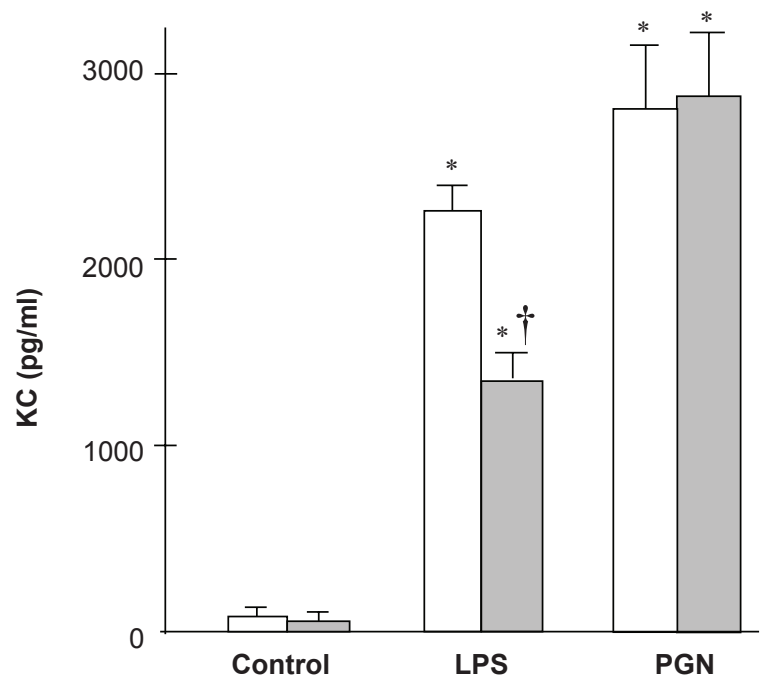

Figure $5 \mathrm{KC}$ concentration in plasma and BAL fluid. (a) Plasma KC was increased after LPS challenge only in C3H/HeN mice ( $<<0.0 \mathrm{I}$ ). (b) In BAL fluid, LPS-induced increase in KC was attenuated by the absence of TLR4 $(\mathrm{p}<0.05)$, whereas PGN-induced upregulation of KC did not differ between the strains.

Notes: Open columns, $\mathrm{C} 3 \mathrm{H} / \mathrm{HeN}$ mice; Gray columns, $\mathrm{C} 3 \mathrm{H} / \mathrm{HeJ}$ mice; Data are presented as the mean $\pm \mathrm{SEM}(\mathrm{n}=6)$; ${ }^{*} \mathrm{p}<0.05$ versus control. ${ }^{\dagger} \mathrm{p}<0.05$ versus $\mathrm{C} 3 \mathrm{H} /$ $\mathrm{HeN}$ mice.

Abbreviations: BAL, bronchoalveolar lavage; LPS, lipopolysaccharide; PGN, peptidoglycan; SEM, standard error of mean; TLR4, Toll-like receptor 4. 
control group, whereas there was no difference in plasma $\mathrm{KC}$ levels between the control and PGN groups.

The plasma CXCL10 level was significantly increased after intratracheal LPS only in $\mathrm{C} 3 \mathrm{H} / \mathrm{HeN}$ mice (Figure 6a). There was a significant difference in the CXCL10 levels after LPS challenge between the two strains examined $(\mathrm{p}<0.01)$. The CXCL10 level in BAL fluid was significantly increased by LPS only in wild type mice (Figure 6b). PGN instillation induced no upregulation of CXCL10 regardless of the mouse strain.

\section{NF- $\kappa B$ translocation}

NF- $\kappa$ B translocation after instillation of PBS, LPS, or PGN was estimated using EMSA of whole lung nuclear extracts at $3 \mathrm{~h}$ (Figure 7). In $\mathrm{C} 3 \mathrm{H} / \mathrm{HeN}$, or wild type mice, LPS caused significant NF- $\kappa B$ translocation in the lungs $(\mathrm{p}<0.001)$, which was attenuated in those with TLR4 gene mutation $(\mathrm{p}<0.05)$. In animals that received PGN instillation, significant NF- $\kappa \mathrm{B}$ translocation was observed, compared with the control mice with PBS instillation $(\mathrm{p}<0.01)$. There was no difference in lung NF- $\kappa \mathrm{B}$ activation after PGN between the two strains examined. These results suggest that LPS-induced NF- $\kappa \mathrm{B}$ translocation may be TLR4-dependent, whereas NF- $\kappa \mathrm{B}$ activation after PGN may not be TLR4dependent.

a

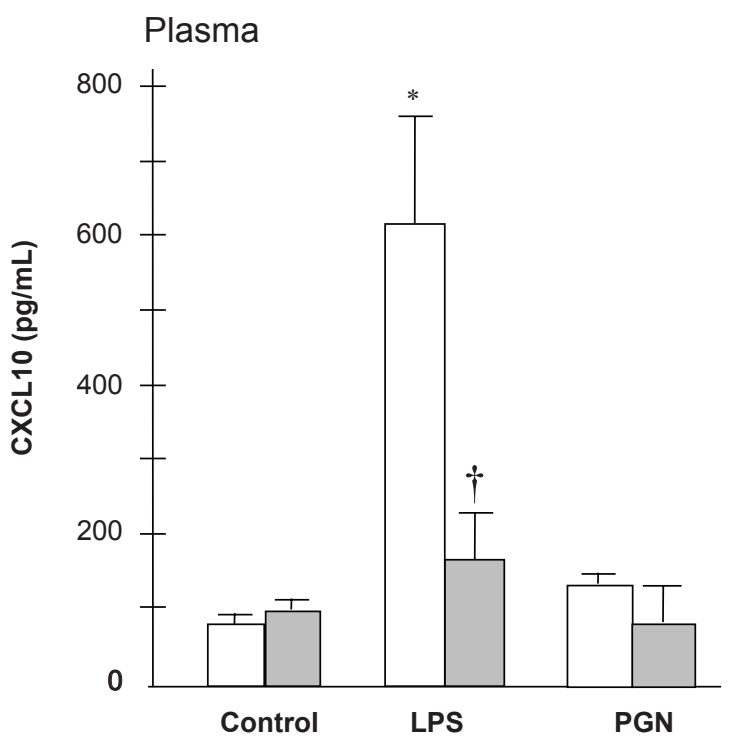

The identities of NF- $\kappa \mathrm{B}$ proteins translocating to the nucleus in response to LPS were investigated with supershift analyses, using antibodies to the p65 (RelA) and p50 subunits (Figure 8). Whereas the levels of NF- $\mathrm{KB}$ proteins in nuclear fractions were decreased in $\mathrm{C} 3 \mathrm{H} / \mathrm{HeJ}$ mice, the bands that were supershifted by Ab against RelA showed comparable intensity regardless of the strain. In contrast, the bands supershifted by the antibody against p50 were lighter in $\mathrm{C} 3 \mathrm{H} / \mathrm{HeJ}$ than in $\mathrm{C} 3 \mathrm{H} / \mathrm{HeN}$ mice, indicating that, in TLR4 mutant mice, the decreased translocation of p50 may be responsible for the attenuated NF- $\mathrm{KB}$ activation following intratracheal LPS. These results suggest that TLR4 gene mutation might inhibit nuclear binding of LPS-induced p65/p50 heterodimer. Another possibility is that the components of NF- $\kappa B$ may be different between the two strains.

\section{Discussion}

TLR4 is a key pattern recognition receptor that is essential for recognition of bacterial LPS, but its role in the inflammatory response to locally administered stimuli has been less clear. In this series of experiments, we evaluated the role of TLR4 in the development of acute lung inflammation after intratracheal challenge of bacterial cell constituents. In TLR4 mutant mice, LPS-induced neutrophil emigration within the lungs was attenuated, whereas PGN-induced emigration was not.

b

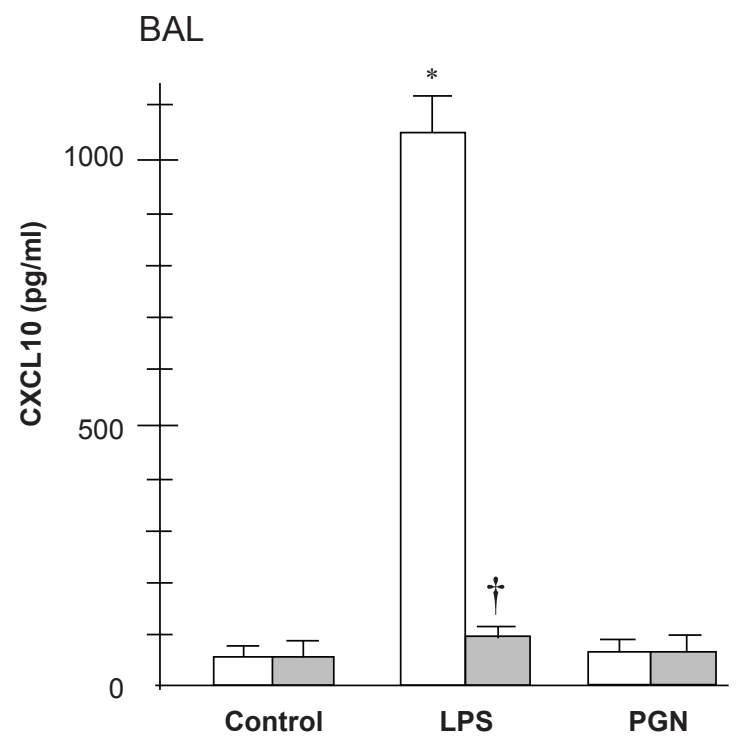

Figure 6 CXCLI0 concentration in plasma and BAL fluid. LPS-induced increase in CXCLI0 in plasma and BAL fluid was attenuated by the absence of TLR4 ( $p<0.01$ ). PGN did not upregulate CXCLIO in plasma or BAL fluid.

Notes: Open columns, $\mathrm{C} 3 \mathrm{H} / \mathrm{HeN}$ mice; Gray columns, $\mathrm{C} 3 \mathrm{H} / \mathrm{HeJ}$ mice; Data are presented as the mean $\pm \mathrm{SEM}(\mathrm{n}=6)$; ${ }^{*} \mathrm{p}<0.05$ versus control; ${ }^{\dagger} \mathrm{p}<0.05$ versus $\mathrm{C} 3 \mathrm{H} /$ $\mathrm{HeN}$ mice.

Abbreviations: BAL, bronchoalveolar lavage; LPS, lipopolysaccharide; PGN, peptidoglycan; SEM, standard error of mean; TLR4, Toll-like receptor 4. 


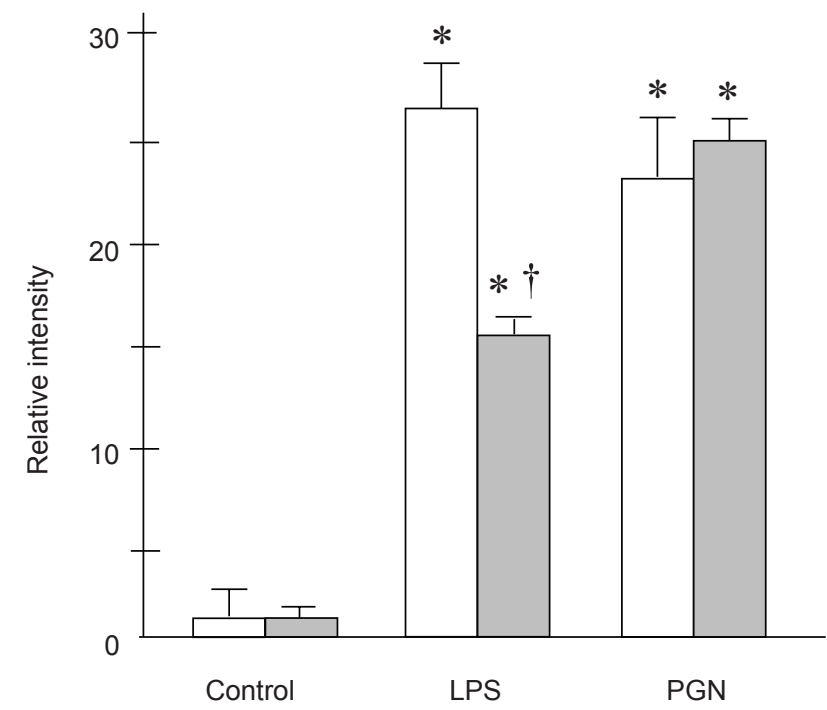

Figure 7 NF- $\kappa B$ translocation in the lungs 3 hours after LPS or PGN instillation. (a) Representative example of the gel appearance. Significant attenuation of NF- $\mathrm{KB}$ translocation was observed in the $\mathrm{C} 3 \mathrm{H} / \mathrm{HeJ}$ mice followed by LPS instillation. (b) LPS-induced translocation of NF- $\kappa B$ was significantly attenuated by the absence of TLR4 ( $p<0.05$ ), whereas PGN-induced NF- $K B$ translocation did not differ between the strains.

Notes: Open columns, $\mathrm{C} 3 \mathrm{H} / \mathrm{HeN}$ mice; Gray columns, $\mathrm{C} 3 \mathrm{H} / \mathrm{HeJ}$ mice; Data are presented as the mean \pm SEM $(n=6) ;{ }^{*}<0.05$ was considered to be significantly different from the corresponding value of the control of the same strain; ${ }^{\dagger} p<0.05$ was considered to be significantly different from the corresponding value of the $\mathrm{C} 3 \mathrm{H} / \mathrm{HeN}$ mice with the same treatment.

Abbreviations: BAL, bronchoalveolar lavage; LPS, lipopolysaccharide; NF- $\kappa B$, nuclear factor-КB; PGN, peptidoglycan; SEM, standard error of mean;TLR4, Toll-like receptor 4 .

LPS-induced expression of proinflammatory cytokine (TNF- $\alpha$ ) and chemokines (KC and CXCL10) in plasma and BAL fluid was significantly attenuated in TLR4 mutant mice. In addition, NF- $\mathrm{KB}$ translocation after LPS was significantly attenuated in TLR4 mutant mice, whereas TLR4 gene mutation made no significant difference in PGN-induced NF- $\kappa B$ activation. We believe that these results suggest that TLR4 might play an important role in the development of acute lung inflammation after intratracheal instillation of LPS, a component of gram-negative bacteria.

Although there have been several reports about the importance of TLR4 in the inflammatory response to LPS, most of them described in vitro studies or an animal model of systemic administration of LPS (Schwartz 2001; Fan et al 2003; Zhou et al 2005). The effect of TLR4 deficiency on lung inflammatory change following locally administered stimuli has not been evaluated quantitatively.

In $\mathrm{C} 3 \mathrm{H} / \mathrm{HeJ}$ mice, the missense mutation in the intracytoplasmic domain of TLR4 acts as a dominant negative molecule, possibly by sequestrating the downstream adaptor and signaling molecules (eg, MyD88 and IRAK1), and prevents LPS-induced signaling and NF- $\mathrm{KB}$

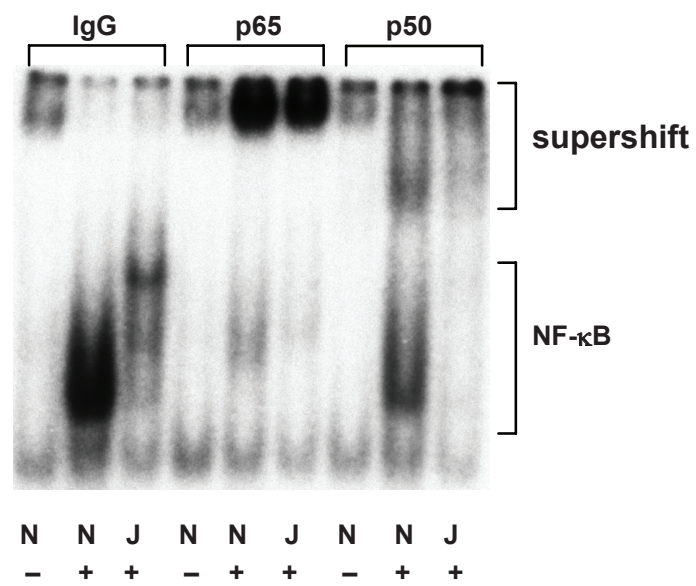

Figure 8 Supershift analysis revealed a decrease in NF- $K B$ in nuclear fractions in $\mathrm{C} 3 \mathrm{H} / \mathrm{HeJ}$ mice. The bands that were supershifted by $\mathrm{p} 65$ showed similar intensity regardless of the strain. In contrast, the bands supershifted by Ab against $\mathrm{p} 50$ was lesser in $\mathrm{C} 3 \mathrm{H} / \mathrm{HeJ}$ than in $\mathrm{C} 3 \mathrm{H} / \mathrm{HeN}$ mice.

Abbreviation: NF- $\kappa B$, nuclear factor- $\kappa B$.

activation (Poltorak et al 1998; Vogel et al 1999). Lack of TLR4-associated signaling results in the impaired transcription of various inflammatory mediators and adhesion molecules (Faure et al 2000; Li and Cherayil 2004). Although, in $\mathrm{C} 3 \mathrm{H} / \mathrm{HeJ}$ mice, attenuated response to systemic inflammation such as sepsis and impaired bacterial clearance in the lung have been reported, there have been few reports comparing the pulmonary inflammatory responses induced by LPS and PGN between TLR4 mutant and wild type mice (Wang et al 2002; Lee et al 2005).

In the present study, we observed that PGN from Staphylococcus aureus caused similar degrees of neutrophil accumulation in $\mathrm{C} 3 \mathrm{H} / \mathrm{HeN}$ and $\mathrm{C} 3 \mathrm{H} / \mathrm{HeJ}$ mice. Whereas $S$. aureus has been shown to be recognized by TLR2 (Takeuchi et al 1999), the role of TLR4 in the inflammatory process initiated by Gram-positive organisms remains controversial (Malley et al 2003; Branger et al 2004). Further investigation will be needed to elucidate the role of TLRs in infection of gram-positive organisms.

Takeuchi and colleagues (1999) showed that S. aureus cell wall-mediated TNF- $\alpha$ production was fully dependent on TLR2, which coincides with our finding that TNF- $\alpha$ levels in plasma and BAL fluid after PGN was not different between the two strains examined. In this study, the plasma IFN- $\gamma$ level after PGN instillation was significantly greater in TLR4 mutant mice, although in PGN-treated animals, none of the other mediators differ between the two strains. Since TNF- $\alpha$ plays a central role in the acute inflammatory response (Mizgerd et al 2004), the absence of a TLR4-mediated signaling pathway might have upregulated 
alternative pathways, leading to the enhanced IFN- $\gamma$ production after PGN challenge. Further investigation will be needed to elucidate the role of TLR2 in the wallmediated cytokine production, such as using the TLR2 mutant mice.

$\mathrm{KC}$ has been reported to be associated with neutrophil recruitment into the lung vascular compartment as well as neutrophil activation (Frevert et al 1995). In this study, we observed a significant decrease in LPS-induced KC production in TLR4 mutant mice, a result which agrees with a previous report (Ramphal et al 2005). In PGNtreated animals, however, plasma $\mathrm{KC}$ levels remained as low as in the control mice, which suggest that $\mathrm{KC}$ might not contribute to the recruitment of circulating neutrophils in response to PGN.

CXCL10 plays important roles in the host innate immune response to bacterial infection (Narumi and Hamilton 1991; Michalec et al 2002; Re and Strominger 2004). In the present study, we observed a marked decrease in LPS-induced CXCL10 production in TLR4-mutants, suggesting that TLR4-mediated signaling may be responsible for CXCL10 production. Although CXCL10 production is induced by IFN- $\gamma$, the upregulation of IFN- $\gamma$ and CXCL10 was not parallel. In addition to the direct effect of LPS on CXCL10 production, we speculate that the induction of CXCL10 by IFN- $\gamma$ might have not occurred 6 hours after the PGN challenge.

The intrapulmonary deposition of bacteria or their cell constituents induce the nuclear translocation of NF- $\kappa B$ complexes, including p65 (RelA) and p50 subunits (Doerschuk et al 1999). It is still controversial as to which subunit is essential for effectively responding to bacterial stimuli in the lungs (Alcamo et al 2001; Mizgerd et al 2002). In this study, we observed lesser p50 in the TLR4 mutant than in wild type mice, indicating that, in TLR4 mutants, the decreased translocation of p50 may contribute to the attenuated NF- $\mathrm{KB}$ activation following intratracheal LPS. Although our data can not elucidate whether the p50 activity observed was homo-dimer or with BCL-3, the p50 subunit may play a more significant role in LPS-induced neutrophil accumulation in the absence of the TLR4 signaling pathway.

\section{Conclusion}

TLR4 plays an important role in the development of LPS-induced lung inflammation through differential upregulation of TNF- $\alpha$ and chemokines, whereas the inflammatory response to intratracheally administered PGN was independent of TLR4. TLR4 contributes to the pathogenesis of pneumonia caused by Gram-negative organisms as well as systemic inflammation such as sepsis.

\section{Acknowledgments}

This work was supported by a grant-in-aid for Scientific Research (B), Ministry of Education, Science, Sports and Culture, 16390457. The authors report no conflicts of interest in this work.

\section{References}

Akira S, Uematsu S, Takeuchi O. 2006. Pathogen recognition and innate immunity. Cell, 124:783-801.

Alcamo E, Mizgerd JP, Horwitz BH, et al. 2001. Targeted mutation of TNF receptor I rescues the RelA-deficient mouse and reveals a critical role for NF-kappa B in leukocyte recruitment. J Immunol, 167:1592-600.

Branger J, Knapp S, Weijer S, et al. 2004. Role of Toll-like receptor 4 in grampositive and gram-negative pneumonia in mice. Infect Immun, 72:788-94.

Ciesielski CJ, Andreakos E, Foxwell BM, et al. 2002. TNF $\alpha$-induced macrophage chemokine secretion is more dependent on NF- $\kappa \mathrm{B}$ expression than lipopolysaccharides-induced macrophage chemokine secretion. Eur J Immunol, 32:2037-45.

Ding K, Shibui A, Wang Y, et al. 2005. Impaired recognition by Tolllike receptor 4 is responsible for exacerbated murine Pneumocystis pneumonia. Microbes Infect, 7:195-203.

Doerschuk CM, Mizgerd JP, Kubo H, et al. 1999. Adhesion molecules and cellular biomechanical changes in acute lung injury: Giles F. Filley Lecture. Chest, 116:37S-43S

Fan J, Frey RS, Malik AB. 2003. TLR4 signaling induces TLR2 expression in endothelial cells via neutrophil NADPH oxidase. J Clin Invest, 112:1234-43.

Faure E, Equils O, Sieling PA, et al. 2000. Bacterial lipopolysaccharide activates NF- $\kappa$ B through Toll-like receptor 4 (TLR-4) in cultured human dermal endothelial cells. J Biol Chem, 275:11058-63.

Faure K, Sawa T, Ajayi T, et al. 2004. TLR4 signaling is essential for survival in acute lung injury induced by virulent Pseudomonas aeruginosa secreting type III secretory toxins. Respir Res, $5: 1-10$.

Frevert CW, Huang S, Danaee H, et al. 1995. Functional characterization of the rat chemokine $\mathrm{KC}$ and its importance in neutrophil recruitment in a rat model of pulmonary inflammation. J Immunol, 154:335-44.

Hogg JC, Doerschuk CM. 1995. Leukocyte traffic in the lung. Annu Rev Physiol, 57:97-114.

Lee JS, Frevert CW, Matute-Bello G, et al. 2005. TLR-4 pathway mediates the inflammatory response but not bacterial elimination in $E$. coli pneumonia. Am J Physiol Lung Cell Mol Physiol, 289:L731-8.

Li Q, Cherayil BJ. 2004. Toll-like receptor 4 mutation impairs the macrophage TNF-alpha response to peptidoglycan. Biochem Biophys Res Commun, 325:91-6.

Malley R, Henneke P, Morse SC, et al. 2003. Recognition of pneumolysin by Toll-like receptor 4 confers resistance to pneumococcal infection. Proc Natl Acad Sci U S A, 100:1966-71.

Michalec L, Choudhury BK, Postlethwait E, et al. 2002. CCL7 and CXCL10 orchestrate oxidative stress-induced neutrophilic lung inflammation. J Immunol, 168:846-52.

Mizgerd JP, Scott ML, Spieker MR, et al. 2002. Function of I B proteins in inflammatory responses to Eschericha coli LPS in mouse lungs. Am J Respir Cell Mol Biol, 27:575-81.

Mizgerd JP, Lupa MM, Hjoberg J, et al. 2004. Roles for early response cytokines during Escherichia coli pneumonia revealed by mice with combined deficiencies of all signaling receptors for TNF and IL-1. Am J Physiol Lung Cell Mol Physiol, 286:L1302-10. 
Narumi S, Hamilton TA. 1991. Inducible expression of murine IP-10 mRNA varies with the state of macrophage inflammatory activity. J Immunol, 146:3038-44.

Pahl HL. 1999. Activators and target genes of Rel/NF- $\kappa$ B transcription factors. Oncogene, 18:6853-66.

Poltorak A, He X, Smirnova I, et al. 1998. Defective LPS signaling in $\mathrm{C} 3 \mathrm{H} / \mathrm{HeJ}$ and $\mathrm{C} 57 \mathrm{BL} / 10 \mathrm{ScCr}$ mice: Mutation in Tlr4 gene. Science, 282:2085-8.

Ramphal R, Balloy V, Huerre M, et al. 2005. TLRs 2 and 4 are not involved in hypersusceptibility to acute $P$ seudomonas aeruginosa lung infections. J Immunol, 175:3927-34.

Re F, Strominger JL. 2004. IL-10 released by concomitant TLR2 stimulation blocks the induction of a subset of Th1 cytokines that are specifically induced by TLR4 or TLR3 in human dendritic cells. J Immunol, 173:7548-55.

Schurr JR, Young E, Byrne P, et al. 2005. Central role of Toll-like receptor 4 signaling and host defense in experimental pneumonia caused by gram-negative bacteria. Infect Immun, 73:532-45.

Schwartz DA. 2001. The role of TLR4 in endotoxin responsiveness in humans. J Endotoxin Res, 7:389-93.

Strieter RM, Belperio JA, Keane MP. 2002. Cytokines in innate host defense in the lung. J Clin Invest, 109:699-705.
Takeuchi O, Hoshino K, Kawai T, et al. 1999. Differential roles of TLR2 and TLR4 in recognition of gram-negative and gram-positive bacterial cell wall components. Immunity, 11:443-51.

Tasaka S, Ishizaka A, Yamada W, et al. 2003. Effect of CD14 blockade on endotoxin-induced acute lung injury in mice. Am J Respir Cell Mol Biol, 29:252-8.

Vogel SN, Johnson D, Perera PY, et al. 1999. Functional characterization of the effect of the $\mathrm{C} 3 \mathrm{H} / \mathrm{HeJ}$ defect in mice that lack an Lpsn gene: in vivo evidence for a dominant negative mutation. $J$ Immunol, 162:5666-70

Wang X, Moser C, Louboutin JP, et al. 2002. Toll-like receptor 4 mediates innate immune responses to Haemophilus influenzae infection in mouse lung. J Immunol, 168:810-5.

Yamamoto M, Takeda K, Akira S. 2004. TIR domain-containing adaptors define the specificity of TLR signaling. Mol Immunol, 40:861-8.

Zhou X, Gao XP, Fan J, et al. 2005. LPS activation of Toll-like receptor 4 signals CD11b/CD18 expression in neutrophils. Am J Physiol Lung Cell Mol Physiol, 288:L655-62. 